\title{
ANALISIS PENERAPAN PRINSIP - PRINSIP GOOD CORPORATE GOVERNANCE PADA CV. PETRA KAUSA MEDAN
}

\author{
Muhammad Azhar Nasution \\ Universitas Sumatera Utara \\ azharnasution44@gmail.com
}

\begin{abstract}
ABSTRAK
Perkembangan dunia usaha yang terus meningkat setiap tahunnya menuntut para pelaku bisnis untuk mengembangkan penerapan sistem tata kelola perusahaan yang baru, yaitu tata kelola perusahaan yang baik. Penelitian ini merupakan penelitian kualitatif dengan metode pengumpulan data menggunakan teknik wawancara dan observasi. Tujuan dari penelitian ini adalah untuk mengetahui bagaimana penerapan prinsip-prinsip tata kelola perusahaan yang baik pada perusahaan yaitu CV Petra Kausa Medan. Hasil penelitian menunjukkan bahwa pada prinsip Transparansi, perusahaan telah memberikan informasi kepada pihak internal dan eksternal. Penyampaian kebijakan kepada perusahaan dilakukan secara lisan dan tertulis. Pada prinsip Akuntabilitas, perusahaan memiliki sistem pengendalian internal, ukuran kinerja, serta target perusahaan. Pada prinsip Tanggung jawab, perusahaan telah melaksanakan tanggung jawab sosial perusahaan dengan tidak mencemari lingkungan, dan telah mematuhi peraturan pemerintah. Pada prinsip Independensi, perusahaan tidak memiliki intervensi dari pihak lain. Dalam Kewajaran, setiap bagian dari perusahaan mendapat perlakuan yang sama.
\end{abstract}

Kata Kunci: Transparansi, Akuntabilitas, Tanggung Jawab, Independensi, Kewajaran

\section{PENDAHULUAN}

Di era globalisasi, persaingan bisnis merupakan sesuatu yang lajim dijumpai. Tingkat persaingan yang dihadapi perusahaan semakin kompleks dan semakin tinggi, ditambah lagi dengan keadaan-keadaan yang tidak menentu seperti kondisi politik dan ekonomi suatu negara, perilaku dari para pesaing atau kompetitor, konsumen, suplier, dan kebijakan pemerintah. Dalam menghadapi persaingan bisnis perusahaan memerlukan adanya penerapan Good Corporate Governance (GCG) yang baik.

Pelaksanaan tata kelola perusahaan yang baik, atau dikenal dengan Good Corporate Governance adalah salah satu pilar dari kemajuan perusahaan. GCG mendorong terciptanya persaingan yang sehat dan iklim usaha yang kondusif dan produktif, sehingga ini penting untuk menunjang pertumbuhan dan stabilitas ekonomi yang berkesinambungan (KNKG, 2016). Terdapat 5 (lima) prinsip utama Good Corporate Governance yang diterapkan di Indonesia yang biasa dikenal dengan sebutan TARIF (Dairi, 2016) yaitu pertama Keterbukaan yang berarti terbuka terhadap segala sesuatu hal seperti dalam proses pengambilan keputusan maupun keterbukaan informasi yang tepat dan akurat kepada stakeholders-nya. Kedua Akuntabilitas adalah kejelasan fungsi serta struktur untuk megelola perusahaan dengan baik, ketiga Pertanggungjawaban adalah kepatuhan perusahaan terhadap aturan-aturan yang berlaku seperti masalah pajak atau pun memelihara lingkungan bisnis yang baik dan benar dan sebagainya. Kemudian Kemandirian yaitu kemandirian perusahaan dalam mengelola dengan cara profesional tanpa ada 
intervensi dengan pihak mana pun. Terakhir Kewajaran adalah faktor pendorong serta perlakuan yang adil di antara beragam kepentingan dalam perusahaan

Tata kelola perusahaan diharapkan untuk menaikkan kualitas perusahaan yang bisa menjaga keseimbangan antara berbagai kepentingan sehingga dapat menguntungkan perusahaan. Pihak eksternal yang kurang berpengetahuan juga bisa melihat baik atau tidaknya perusahaan dengan melihat penilaian dari IICG yaitu CGPI. Semakin tinggi penilaian tata kelola perusahaan berarti perusahaannya semakin terpercaya, transparan, akuntabilitas dan mandiri dan begitu pula dengan sebaliknya (Wahyudin \& Solikhah, 2017)

CV Petra Kausa merupakan salah satu perusahaan dikota medan yang bergerak dalam usaha pengadaan barang dan jasa. Sebagaimana diketahui Pengadaan merupakan suatu kegiatan yang berkaitan dengan pemenuhan/penyediaan sumber daya (Barang dan Jasa) pada suatu proyek tertentu. Pengadaan barang/jasa atau yang lebih dikenal dengan lelang telah banyak dilakukan oleh semua pihak baik dari pemerintah maupun swasta. CV Petra kausa agar terus bertahan dan semakin mengembangkan usahanya di Era Modern seperti sekarang ini perlu untuk menerapkan tata Kelola perusahaan yang baik dengan berdasar pada prnsip-prinsip Good Corporate Governance sehingga dapat memajukan

\section{STUDI LITERATUR}

\section{Pengertian Good Corporate Govermance}

Good Governance adalah meliputi seluruh aspek kehidupan berupa hukum, politik, ekonomi dan sosial (Ihyaul \& Sofyani, 2016). Good Governance juga sangat berhubungan erat dengan penyelenggaraan kekuasaan negara, baik eksekutif, legislatif dan yudikatif. Corporate Governance juga didefinisikan sebagai suatu sistem pengendali internal perusahaan yang memiliki tujuan utama mengelolah risiko yang signifikan guna memenuhi tujuan bisnisnya melalui pengamanan asset perusahaan dan meningkatkan niali investasi pemegang saham dalam jangka (Efendi, 2016).

Menurut Bank Dunia, Good Corporate Governance adalah aturan, standar, dan organisasi di bidang ekonomi yang mengatur perilaku pemilik perusahaan, direktur dan manajer serta perincian dan penjabaran tugas dan wewenang serta pertanggungjawabannya kepada investor 12 (pemegang saham dan kreditur). Tujuannya untuk menciptakan sistem pengendalian dan keseimbangan dalam mencegah penyalahgunaan sumber daya perusahaan dan tetap mendorong terjadinya pertumbuhan perusahaan (Hamdani, 2016)

Good Corporate Governance dalam pengertian yang luas dan dalam sudut pandang yang sempit yang tidak hanya melihat hubungan perusahaan dengan para pemangku kepentingannya saja dalam setiap negara terdapat perbedaan yang disebabkan oleh berbagai faktor seperti kerangka hukum, maupun halhal yang tidak tertulis. Hamdani juga menyampaikan prinsip-prinsip dari Good Corporate Governance yaitu: transparansi, akuntabilitas, responsibilitas, independensi serta kewajaran dan kesetaraan. (Hamdani, 2016)

\section{Prinsip Good Corporate Governance}

Penerapan Prinsip Good Corporate Governance adalah hal yang penting maka prinsip Independensi, Transparansi dan pengungkapan, Akuntabilitas, Pertanggungjawaban, serta Kewajaran harus menjadi landasan utama bagi aktivitas komite audit.

a. Prinsip Independensi

Komite audit diharapkan dapat bersikap independen terhadap kepentingan pemegang saham mayoritas maupun minoritas. Selain itu, anggota komite audit seharusnya tidak memiliki hubungan bisnis apapun dengan perusahaan maupun hubungan kekeluargaan dengan anggota direksi dan komisaris perusahaan, sehingga terhindar dari benturan kepentingan.Oleh karena itu, nama-nama anggota komite audit (terutama di perusahaan publik) hendaknya diumumkan ke masyarakat atau publik sebagai wujud akuntabilitas terhadap sikap independensi mereka. Hal ini penting agar 
masyarakat dapat melakukan kontrol sosial serta penilaian terhadap para anggota komite audit tersebut.

b. Prinsip Transparansi

Prinsip ini ditunjukkan melalui piagam komite audit, program kerja tahunan, serta rapat komite audit secara periodik yang didokumentasikan dalam notulen rapat. Komite audit hendaknya membuat laporan secara berkala kepada komisaris tentang pencapaian kinerjanya sebagai wujud pengungkapan. Diharapkan agar laporan tersebut dituangkan dalam laporan tahunan perusahaan yang dipublikasikan kepada publik.

c. Prinsip Akuntabilitas

Prinsip ini ditunjukkan oleh frekuensi pertemuan dan tingkat kehadiran anggota komite audit. Selain itu, komite audit seharusnya memiliki kapabilitas, kompensasi, dan pengalaman di bidang audit serta proses bisnis perusahaan agar dapat bekerja secara professional.

d. Prinsip Pertanggungjawaban

Prinsip ini ditunjukkan oleh aktivitas komite audit yang dijalankan sesuai dengan peraturan dan ketentuan yang berlaku. Selain itu, kinerja komite audit hendaknya dapat dipertanggungjawabkan secara moral kepada publik, selain kepada dewan komisaris.

e. Prinsip Kewajaran

Keadilan dan kesetaraan dalam memenuhi hak-hak pemangku kepentingan yang timbul sebagai akibat dari perjanjian dan perundang-undangan yang berlaku.

\section{Penelitian Terdahulu}

1. Penelitian yang dilakukan Oleh (Chan, 2019) yang berjudul Analisis Penerapan Prinsip-Prinsip Good Corporate Governance Pada PT Sumber Baru Wisata, Penelitian ini menggunakan jenis penelitian kualitatif deskriptif dengan metode wawancara. Hasil penelitian ini menunjukkan bahwa perusahaan sudah menerapkan prinsip-prinsip Good Corporate Governance yaitu Keterbukaan, Akuntabilitas, Tanggung Jawab, Kemandirian, Kesetaraan dan Kewajaran. Namun, dari penerapan prinsip-prinsip ini, masih ada yang perlu dikembangkan oleh perusahaan seperti dari keterbukaan visi dan misi perusahaan belum terdapat pada website perusahaan, akuntabilitas dimana perusahaan harus menambahkan audit eksternal, dari segi tanggung jawab perusahaan juga dapat menambahkan program Corporate Social Responsibility yang berkelanjutan.

2. Penelitian yang dilakukan Oleh (Friendly, 2017) yang berjudul Analisis Penerapan PrinsipPrinsip Good Corporate Governance Pada Perusahaan Milik Keluarga Bidang Perhotelan, Penelitian ini menggunakan metode kualitatif. Perolehan data dilakukan dengan proses wawancara, Hasil penelitian menunjukkan bahwa subjek penelitian sudah menerapkan sebagian komponen di dalam prinsip TARIF. Perusahaan belum menerapkan prinsip Transparency dengan sempurna karena perusahaan belum memiliki visi dan misi serta website perusahaan untuk diakses oleh pemangku kepentingan. Prinsip Accountability juga belum diterapkan dengan sempurna karena struktur perusahaan yang belum sesuai dengan peraturan pemerintah dan kode etik yang masih disampaikan secara lisan.

3. Penelitian yang dilakukan (Sukardika, Purnama Anggara, \& Wistama, 2020) yang berjudul Pengaruh Penerapan Prinsip-Prinsip Good Corporate Governance pada Kinerja Bank Perkreditan Rakyat di Kabupaten Badung, Penelitian ini menggunakan metode survei dengan teknik kuesioner yang di sebar ke 37 BPR. Sampel yang digunakan sebanyak 74 dan masing masing diambil dua responden dari tiap BPR di bagian keuangan dan di bagian umum yang terdapat di Kabupaten Badung, Penelitian ini menunjukkan hasil bahwa penerapan prinsipprinsip Good Corporate Governance yang meliputi Transparansi, Akuntabilitas, Responsibilitas, Independensi serta kewajaran berpengaruh positif pada kinerja Bank Perkreditan Rakyat di Kabupaten Badung. 


\section{Jenis Penelitian}

\section{METODE PENELITIAN}

Penelitian ini menggunakan penelitian kualitatif. Metode penelitian kualitatif adalah metode penelitian yang bersifat kompleks, utuh, penuh dengan makna yang digunakan untuk meneliti kondisi obyek secara netral atau alamiah dan peneliti pada penelitian ini berperan sebagai sebuah instrumen kunci (Sugiono, 2017). Teknik pengumpulan data pada penelitian ini dilakukan dengan gabungan observasi, wawancara, dokumentasi dan data-data ini cenderung bersifat induktif dan hasilnya berguna untuk memahami makna, keunikan, fenomena dan akhirnya menemukan hipotesis

\section{Objek Penelitian}

Objek penelitian ini adalah penerapan prinsip-prinsip Good Corporate Governance yaitu Transparansi, Akuntabilitas, Responsibilitas, Independensi, Kewajaran dan Kesetaraan atau TARIF pada CV Petra Kausa

\section{Subjek Penelitian}

Dalam penelitian ini, yang menjadi subjek penelitian sebagai sumber data utama adalah CV Petra Kausa Medan yang bergerak di bidang pengadaan barang dan jasa alamat di Jalan Eka Rasmi VI No.9 Medan

\section{Sumber Data}

\section{Data Primer}

Data primer adalah sumber data yang langsung diberikan kepada pengumpul data. Sumber primer dapat berguna untuk menjawab pertanyaanpertanyaan (Sugiono, 2017). Dalam penelitian ini pengumpulan data primer pada CV Petra Kausa menggunakan wawancara dan observasi

\section{Data Sekunder}

Data Sekunder adalah data yang secara tidak langsung memberikan sumbernya kepada pengumpul data seperti melewati orang lain atau dokumen (Sugiono, 2017). Data sekunder pada CV Petra Kausa didapatkan dengan data peraturan perusahaan, profil perusahaan, deskripsi pekerjaan perusahaan

\section{Teknik Analisis Data}

Dalam menganalisis data penelitian kualitatif yang didapatkan dari penelitian, ada beberapa aktivitas proses ketika melakukan analisis data yaitu:

1. Pengumpulan

Data Kegiatan dalam pengumpulan data kualitatif pada umumnya dilakukan melalui observasi, wawancara, dan dokumentasi atau gabungan dari tiga hal tersebut.

2. Reduksi Data

Kegiatan ini dilakukan dengan melakukan analisis data yang telah didapatkan dan melakukan rangkuman, memilih hal-hal yang pokok atau penting dan mencari polanya sehingga mendapatkan gambaran yang lebih jelas sehingga peneliti lebih termudahkan dalam melakukan pengumpulan data

3. Penyajian Data

Penyajian Data dalam penelitian Kualitatif biasanya menggunakan pie chart, pictogram, tabel, grafik dan sejenisnya. Yang paling sering digunakan untuk menyajikan data adalah teks yang bersif

4. Penarikan Kesimpulan / Verifikasi

Kesimpulan akan bersifat sementara dan berubah bila tidak ada bukti-bukti yang mendukung pada tahap pengumpulan data berikutnya. Namun jika hasil didukung dengan bukti yang valid dilapangan maka kesimpulan yang diutarakan dapat menjadi kesimpulan yang kredibel

\section{HASIL DAN PEMBAHASAN}

Penerapan Prinsip Good Corporate Governance pada perusahaan Untuk melaksanakan Good Corporate Governance dibutuhkan prinsip-prinsip sehingga pelaksanaannya bisa berjalan dengan baik. Sesuai dengan (KNKG, 2016) terdapat 5 prinsip - prinsip yang terkandung dalam Good Corporate Governance, yaitu Transparansi, Akuntabilitas, Responsibilitas, Independensi serta kewajaran. Penjabaran dari prinsip-prinsip yang telah dilakukan di dalam perusahaan seperti di bawah ini. 


\title{
Transparansi
}

Informasi pada perusahaan diberikan secara terbuka kepada karyawan. Informasi yang diberikan adalah informasi mengenai visi, misi, peraturan, target yang ada. Setiap informasi yang didapat akan disampaikan langsung kepada karyawan yang bersangkutan. Selain penyampaian secara langsung, perusahaan juga menggunakan media untuk penyampaian informasi kepada karyawan yaitu melalui email, Whatsapp dan telepon. Penggunaan media dalam penyampaian informasi dilakukan apabila pihak yang bersangkutan ketika mendapat informasi tersebut tidak berada di satu tempat yang sama. Berdasarkan observasi peneliti, perusahaan menyediakan computer /laptop, dan akses internet, di perusahaan selain itu setiap karyawan juga memiliki telepon selurer. Setiap informasi yang didapat tidak langsung disampaikan kepada karyawan. Ada beberapa informasi yang diolah terlebih dahulu oleh pimpinan ataupun komisaris, kemudian setelah mencapai kesimpulan barulah informasi akan disampaikan kepada karyawan. Selain keterbukaan informasi internal, ada juga keterbukaan informasi kepada pihak eksternal seperti konsumen atau khalayak ramai. saat ini perusahaan melakukan keterbukaan informasi kepada masyarakat, pemerintah, dan pihak lainnya yang berkepentingan. Selain itu, perusahaan juga belum memiliki website dan hanya menyediakan email bagi pihak luar yang ingin mendapatkan informasi, dan telepon. Untuk konsumen, perusahaan memberikan penjelasan mengenai prosedur dan sasaran dalam pengadaan barang dan jasa. Untuk kebijakan perusahaan setiap kebijakan yang telah diputuskan akan disampaikan secara lisan dan tertulis. Setiap kebijakan yang diambil memiliki evaluasi yang dilakukan setidaknya tiga bulan sekali dengan cara mengumpulkan karyawan untuk menceritakan masalah yang dihadapi setelah itu akan diadakan rapat untuk menilai apakah kebijakan yang ditetapkan akan terus diterapkan atau harus diubah.

\begin{abstract}
Akuntabilitas
Perusahaan memiliki sistem pengendalian internal yang terdiri dari : struktur organisasi perusahaan, rincian tugas. Untuk menetapkan rincian tugas dan tanggung jawab organ perusahaan dan semua karyawan secara jelas dan sesuai dengan nilai-nilai perusahaan dan strategi perusahaan, pada perusahaan terdapat job description. Untuk mengetahui bahwa organ perusahaan dan semua karyawan mempunyai kemampuan sesuai dengan tugas dan tanggung jawab. Perusahaan melakukan interview pada saat perekrutan karyawan. Perekrutan karyawan pada perusahaan saat ini hanya berdasarkan koneksi, dan tidak menggunakan media iklan, internet dan sebagainya. Selain pengukuran kinerja yang dijelaskan diatas perusahaan juga mengukur kinerja karyawannya berdasarkan target yang dicapai. Selain target, perusahaan juga melihat evaluasi dan laporan dari manajer. Untuk punishment tidak di lakukan oleh perusahaan apabila karyawan yang bersangkutan tidak hadir minimal 2 Kali berturut-turut, punishment juga diberikan apabila karyawan yang bersangkutan melakukan pelanggaran, maka akan diberikan surat peringatan sebanyak 3 kali hingga diberhentikan. PHK perusahaan terhadap karyawan juga didasarkan pada aturan yang berlaku tidak berdasarkan PHK sepihak saja, misalnya PHK dilakukan apabila karyawan yang bersangkutan melakukan kecurangan, tetapi untuk saat ini perusahaan belum mengalami hal seperti yang disebutkan di atas. Untuk target perusahaan adalah untuk memasuki pasar yang lebih luas lagi dan mengikuti tender proyek yang lebih banyak dan besar lagi dalam pelaksanaannya belum ada strategi khusus, dan perusahaan baru menyiapkan surat - surat yang dibutuhkan untuk dapat mengikuti tender proyek.
\end{abstract}

\section{Responsibilitas}

Perusahaan tidak melakukan CSR terhadap lingkungan karena perusahaan bukan merupakan perusahaan produksi melainkan perusahaan pengadaan barang dan jasa serta belum memiliki penghasilan yang berskala besar, serta juga tidak memiliki limbah yang dapat mengganggu lingkungan sekitar perusahaan. Hal itu terlihat dari lingkungan perusahaan dimana tidak adanya limbah produksi. Sedangkan untuk di lingkungan perusahan dengan mengingat isu go-green yang saat ini yang sedang ramai dibicarakan, di likungan perusahaan masih belum adanya tanaman hijau. CSR yang perusahaan terapkan saat ini terhadap masyarakat adalah dengan tidak mencemari lingkungan seperti tidak membuang sampah sembarangan. Berdasarkan observasi peneliti, pada perusahaan terdapat tempat sampah serta lingkungan perusahaan yang bersih dan perusahaan juga tidak membuat keributan yang 
dapat mengganggu masyarakat sekitar misalnya kegiatan operasional perusahaan yang hanya sampai pukul 17.00 WIB dari hari senin sampai Jumat, sehingga tidak mengganggu jam istirahat masyarakat sekitar. Untuk saat ini perusahaan belum melakukan CSR pada masyarakat yang berupa upaya membantu misalnya pemberian dana bantuan. Untuk kepatuhan terhadap peraturan pemerintah dilihat dari ketaatan terhadap pembayaran pajak. Perusahaan telah memenuhi kewajibannya kepada Negara dengan menyetor pajak kepada Negara. Perusahaan juga memberikan upah sesuai dengan ketentuan pemerintah mengenai upah minimum. Selain upah, perusahaan juga tidak mempekerjakan tenaga kerja di bawah 17 tahun. Untuk hak konsumen perusahaan tidak membatasi hak- hak konsumen, misalnya hak untuk mendapatkan ganti rugi /penggantian apabila barang yang diterima tidak sesuai dengan perjanjian atau tidak sebagaimana mestinya.

\section{Independensi}

Agar perusahaan dapat menerapkan prinsip kemandirian ini, perusahaan harus melakukan pengelolaan secara mandiri atau independen sehingga masing-masing bidang perusahaan tidak bisa saling mendominasi dan tidak dapat diintervensi oleh pihak lain (KNKG, 2016). Informasinya berupa cara menghindari conflict of interest, menghindari intervensi dalam pengambilan keputusan dari pihak lain, perbedaan kepentingan antara pemegang saham, wewenang pengambilan keputusan, pelemparan tanggung jawab organ perusahaan. Perusahaan telah menerapkan prinsip kemandirian dalam aspek menghindari conflict of interest. Tiap bagian perusahaan selalu mengutamakan pekerjaan dengan kepentingan perusahaan merupakan kepentingan utama. Selain itu, tiap bagian yang ada di perusahaan adalah berdasarkan profesional tanpa memiliki afiliasi dengan pemilik perusahaan atau kepentingankepentingan tertentu. Perusahaan juga telah menerapkan prinsip kemandirian dalam hal intervensi dari pihak tidak berwenang dalam pengambilan keputusan karena hingga sekarang belum terdapat intervensi karena ketika bekerja masing-masing dengan cara terdapat peraturan yang dituangkan dalam SOP sehingga sudah ada aturan baku. Penarapan kemandirian dalam pengambilan keputusan juga telah diterapkan oleh perusahaan. Hal ini seperti pemberian wewenang oleh pimpinan sesuai kewenangan masing-masing. Selain itu, perusahaan juga tidak pernah terdapat pelemparan tanggung jawab bagian perusahaan masing-masing karena sudah terdapat penjelasan masing-masing tugas dan pekerjaan tiap bagian perusahaan.

\section{Kewajaran}

Pada perusahaan setiap pemangku kepentingan mempunyai hak untuk memberikan masukan dan menyampaikan pendapat yang berhubungan dengan kepentingan perusahaan. Misalnya kebijakan perusahaan terhdap karyawannya, semua karyawan berhak memberikan pendapatnya mengenai kebijakan perusahaan yang tidak di setujui, seperti mengenai kebijakan jangka waktu cuti karyawan. Selain itu tidak ada perlakuan yang berbeda terhadap karyawan, yang terlihat dari aspek gender dan agama. Untuk gender, meskipun mayoritas pekerja pada perusahaan ini merupakan karyawan dengan gender atau jenis kelamin laki-laki, pekerja wanita tetap mendapatkan hak nya sebagai pekerja wanita, seperti pekerja wanita tetap memperoleh cuti hamil sesuai dengan peraturan pemerintah mengenai ketenagakerjaan yang berlaku. Pekerja pria dan wanita tetap mendapatkan hak yang sama berupa gaji dan tunjangan serta THR berdasarkan hari raya. Untuk agama, pada perusahaan ini terdapat mayoritas agama Islam. Pada perusahaan tidak ada perbedaan pelakuan terhadap para pekerja, hal ini terlihat setiap jumat pekerja yang beragama Islam diperbolehkan untuk melakukan sholat Jumatan. Sholat Jumatan ini diberi waktu selama 2 jam (1 jam sholat dan 1 jam istirahat makan siang). Untuk proses jenjang karir karyawan pada perusahaan, didasarkan pada kinerja karyawan. Perusahaan memberlakukan punishment. Mengenai punishment, perusahaan memiliki sistem melalui surat peringatan sebanyak tiga kali. Untuk karyawan yang melanggar peraturan maka akan diberikan surat peringatan (SP), SP tersebut dimulai dari SP1 sampai SP3, dan untuk karyawan yang mendapatkan SP ke 3 maka karyawan tersebut diberhentikan. Selain itu narasumber mengatakan bahwa, perusahaan menerapkan sanksi berupa setiap tidak hadir kerja tanpa alsan yang jelas wajib membayar Rp. 50.000,- 


\section{KESIMPULAN}

Penerapan prinsip Transparansi, perusahaan sudah menyediakan informasi kepada karyawan secara transparan. Informasi yang diberikan kepada pihak internal dilakukan dengan jelas, cepat, dan dengan pertimbangan. Perusahaan telah memberikan informasi kepada pihak eksternal. Untuk kebijkan perusahaan disampaikan secara lisan dan tertulis. Penerapan prinsip Akuntabilitas pada perusahaan terlihat bahwa, perusahaan telah memiliki sistem pengendalian internal yang terdiri dari : adanya struktur organisasi perusahaan, serta rincian tugas dan tanggung jawab. Perusahaan juga memiliki ukuran kinerja karyawannya, yaitu dengan melakukan wawancara, berdasarkan target yang dicapai dan melihat evaluasi serta laporan dari manajer. Perusahaan juga memiliki target jangka panjang yaitu untuk memasuki pasar yang lebih besar lagi dan mengikuti tender proyek yang besar walaupun strateginya masih dalam rancangan. Penerapan prinsip Responisbitas, perusahaan sudah melaksanakan corporate social responsibility (CSR) dengan cara tidak mencemari lingkungan dan telah mematuhi peraturan pemerintah. CSR pada perusahaan telah dilakukan meskipun ada beberapa hal yang terlewatkan seperti belum adanya tindakan untuk membantu masyarakat seperti pemberian dana. Sedangkan mengenai peraturan pemerintah, perusahaan telah memenuhi kewajibannya kepada Negara dengan menyetor pajak kepada Negara, meberikan upah sesuai dengan ketentuan upah minimum, tidak mempekerjakan pekerja dibawah umur, tidak membatasi hak konsumen, dan telah menaati peraturan perusahaan. Penerapan prinsip Independensi bahwa setiap karyawan menjalankan tugas dan tanggung jawabnya dengan baik dan benar serta tidak adanya kepentingan lain selain kepentingan untuk memajukan perusahaan. Penerapan prinsip Kewajaran, perusahaan sudah berusahan melaksanakannya. Untuk karyawan, perusahaan tidak mebeda-bedakan semua karyawannya mengenai hak dan kewajiban setiap karyawan. Hal itu terlihat dari setiap karyawan mendapat gaji sesuai dengan jabatan dan kinerjanya. serta adanya punishment. Sedangkan untuk konsumen perusahaan menerima retur barang yang diberikan oleh konsumen berdasarkan peraturan perusahaan mengenai syarat retur barang.

\section{DAFTAR PUSTAKA}

Daniri, Mas Achmad. (2016). Good Corporate Governance, Pengertian dan Konsep Dasar. Jakarta: Graha Ilmu.

Efendi, M. (2016). The Power Of Good Corporate Govermance Teori dan Implementasi. Jakara: Salemba Empat .

Hamdani. (2016). Good Corporate Governance Tinjauan Etika dalam Praktik Bisnis. Jakarta: Mitra Wacana Media.

Ihyaul, U., \& Sofyani, H. (2016). Akuntansi Sektor Publik. Malang: Aditya Media.

Komite Nasional Kebijakan Governance (KNKG). (2006). Pedoman Umum GCG Indonesia, Jakarta.

Sugiyono. (2017). Metode Penelitian Kuantitatif, Kualitatif, dan R\&D. Bandung: Alfabeta.

Shinta Wahyu Hati, Awik Arumrasmy (2017). Prosiding dari Seminar Nasional Membangun Etika Sosial Politik Menuju Masyarakat Yang Berkeadilan di Universitas Lampung. Analisis Penerapan Prinsip Good Corporate Governance Terhadap Kinerja Pegawai Di Politeknik Negeri Batam. Hal 56-76

Wahyudin, Agus \& Solikhah, Badingatus. (2017). Corporate governance implementation rating in Indonesia and its effects on financial performance. Corporate Governance: The International Journal of Business in Society Vol. 17 pp.250- 265 